\title{
How future managers view societal culture: A comparison across seven CEE countries
}

\author{
Doina Catana, Danijel Pučko, Renata Krzykała-Schaefer*
}

The purpose of our exploratory study is to describe the characteristics of a sample of Central and East European students in business and engineering from their cultural assumption perspective. The cluster-distinctive cultural practices are: High Power Distance, In-group and Institutional Collectivism, low Humane and Future Orientation. Expectations (ideals) record significant differences for all cultural dimensions, with the highest ones concerning Power Distance (desire to decrease), Performance Orientation and Humane Orientation (desire to increase). Country of origin influences the students' perceptions to a greater extent than their expectations, letting us presume that some of the societal cultural dimensions in the investigated region might show a trend toward harmonisation.

Ziel dieser explorativen Studie ist es, die Charakteristiken einer Stichprobe aus zentral- und osteuropäischen Studierenden der Wirtschafts- und Ingenieurwissenschaften in Hinblick auf ihre kulturgeprägten Annahmen zu untersuchen. Für diese Region als typisch wahrgenommene Praktiken beziehen sich auf folgende Gesellschaftskulturdimensionen: hohe Machtdistanz, hoher gruppenbezogener und institutioneller Kollektivismus, sowie niedrige Human- und Zukunftsorientierung. Studentische Erwartungshaltungen (Ideale) zeigen von den Praktiken signifikant abweichende Werte für alle Kulturdimensionen, am stärksten ausgeprägt hinsichtlich Machtdistanz (Wunsch nach Reduktion), sowie Leistungs- und Humanorientierung (Wunsch nach Zunahme). Die seitens der Studierenden wahrgenommenen Praktiken sind stärker herkunftslandgeprägt als deren eigene Erwartungshaltungen. Daraus folgern wir, dass die Kulturdimensionen innerhalb dieser Region einem Trend zur Harmonisierung unterliegen, zumindest teilweise.

Key words: GLOBE, CEE countries, students, intercultural differences, societal culture values, societal culture practices, (JEL: J24, M14)

\footnotetext{
* Doina Catana, Professor in Management, Technical University of Cluj-Napoca, Romania. Main research interests: Organisational culture and leadership. Corresponding address: dcatana@eps.utcluj.ro

Danijel Pučko, Professor in Management, University of Ljubljana, Slovenia. Main research interests: Strategic management.

Renata Krzykała-Schaefer, PhD, Lecturer at the Faculty of Management, Poznań School of Banking, Poland. Main research interests: Cross-cultural management, effective global management, development of intercultural skills and competencies of managers in the areas of communication, negotiations and effective (ethical) leadership. Corresponding address: renata.schaefer@wsb.poznan.pl
} 


\section{Introduction}

The present article focuses on one of the GLOBE Student project's objectives, namely finding out the characteristics of future managers from their perceptions on and expectations about societal culture dimensions perspective. An assumption of this project is that future managers will be recruited mostly from today's students of business and engineering. The sample comes from a variety of countries with different size, population, economic development, linguistic origin, religion, Human Development Index etc., sharing at the same time at least the following attributes: political regime (democratic republics; Romania: semi-presidential, all the others: parliamentary), membership in the European Union (different "seniority") and except Austria, membership in the NATO. Table 1 displays the main characteristics of the countries in the sample.

The seven countries represent $28.5 \%$ of the European Union's surface and $33.9 \%$ of its population ${ }^{8}$, thus the findings about the next generation managers' view on societal culture dimensions might be of interest for companies doing business across the European Union, as well as for management schools and training entities.

The research questions the study aims to answer are:

(1) Which are the average cultural characteristics of CEE students from the perspective of culture-related perceptions and expectations?

(2) Which are (if any) the significant differences between the perceived and expected cultural dimensions in the sample?

(3) Is the country of origin a factor explaining the differences in perceptions and expectations?

(4)Are there distinctive homogeneous subsets within the sampled cluster along the cultural dimensions?

Table 1: Characteristics of the countries in the sample

\begin{tabular}{|c|c|c|c|c|c|c|c|}
\hline & 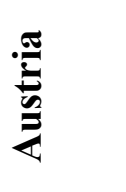 & & 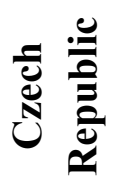 & 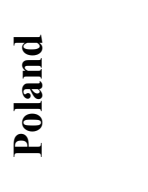 & 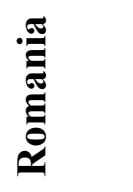 & $\frac{1}{2}$ & $\frac{\frac{\pi}{\pi}}{\frac{\pi}{\pi}}$ \\
\hline $\begin{array}{l}\text { Surface } \\
\text { (sq.km) }\end{array}$ & 83,870 & 357,110 & 78,870 & 312,680 & 238,390 & 49,030 & 20,270 \\
\hline $\begin{array}{l}\text { Popula- } \\
\text { tion (mil. } \\
\text { 2010) }\end{array}$ & 8,380 & 81,640 & 10,530 & 38,180 & 21,450 & 5,430 & 2,060 \\
\hline
\end{tabular}

${ }^{8}$ According to data presented on http://europa.eu/about-eu/facts-figures/living/index_en.htm 


\begin{tabular}{|c|c|c|c|c|c|c|c|}
\hline $\begin{array}{l}\text { Life } \\
\text { expectan- } \\
\text { cy (2009) }\end{array}$ & 80.1 & 79.9 & 77.1 & 75.7 & 73.3 & 79.0 & 74.9 \\
\hline $\begin{array}{l}\text { Percen- } \\
\text { tage of } \\
\text { women }\end{array}$ & 51.2 & 51.0 & 50.9 & 51.8 & 51.4 & 51.5 & 51.2 \\
\hline $\begin{array}{l}\text { GDP (Bill. } \\
\text { \$; 2010) }\end{array}$ & 376,162 & $3.309,669$ & 192,152 & 468,585 & 161,624 & 89,034 & 47,763 \\
\hline $\begin{array}{l}\text { GDP/ } \\
\text { capita } \\
\text { (US curr. } \\
\text { \$; 2010) }\end{array}$ & 44,879 & 40,542 & 18,239 & 12,274 & 7,535 & 16,397 & 23,129 \\
\hline $\begin{array}{l}\text { Dominant } \\
\text { religion }\end{array}$ & $\begin{array}{c}\text { R. Cath.: } \\
73.6 \%{ }^{1}\end{array}$ & $\begin{array}{c}\text { R. Cath. } \\
34 \% \\
\text { Protest: } \\
34 \%^{2}\end{array}$ & $\begin{array}{c}\text { R. Cath: } \\
26.8 \% \\
(59 \% \\
\text { atheists })^{3}\end{array}$ & $\begin{array}{l}\text { R.Cath: } \\
94 \%{ }^{4}\end{array}$ & $\begin{array}{c}\text { Orthodox } \\
86.8 \%^{5}\end{array}$ & $\begin{array}{c}\text { R. Cath: } \\
69 \%^{6}\end{array}$ & $\begin{array}{l}\text { R. Cath: } \\
57.8 \%^{7}\end{array}$ \\
\hline $\begin{array}{l}\text { Language } \\
\text { group }\end{array}$ & $\begin{array}{l}\text { Ger- } \\
\text { manic }\end{array}$ & Germanic & Slavic & Slavic & Romance & Slavic & Slavic \\
\hline $\begin{array}{l}\text { Human } \\
\text { Develop- } \\
\text { ment } \\
\text { Index }\end{array}$ & $\begin{array}{c}0.851 \\
\text { (rank 25) }\end{array}$ & $\begin{array}{c}0.885 \\
\text { (rank 10) }\end{array}$ & $\begin{array}{c}0.841 \\
\text { (rank 28) }\end{array}$ & $\begin{array}{c}0.795 \\
(\operatorname{rank} 41)\end{array}$ & $\begin{array}{c}0.767 \\
\text { (rank 51) }\end{array}$ & $\begin{array}{c}0.818 \\
\text { (rank 35) }\end{array}$ & $\begin{array}{c}0.828 \\
\text { (rank 29) }\end{array}$ \\
\hline $\begin{array}{l}\text { Nr. of } \\
\text { students } \\
\text { in tertiary } \\
\text { education/ } \\
1000 \\
\text { inhabi- } \\
\text { tants) }\end{array}$ & 34.0 & 27.5 & 37.3 & 56.7 & 49.3 & 42.3 & 55.8 \\
\hline
\end{tabular}

Source: World Bank: http://data.worldbank.org/data-catalog

${ }^{1} \mathrm{http}: / / \mathrm{www}$. state.gov/r/pa/ei/bgn/3165.htm

${ }^{2} \mathrm{http}: / / \mathrm{www}$. state.gov/r/pa/ei/bgn/3997.htm. These data are for Germany as a whole. In East Germany, which is the focus of our sample, the number of people without religious orientation is much higher.

${ }^{3}$ Hamplova/Nespor (2009)

${ }^{4} \mathrm{http}: / / \mathrm{www}$. state.gov/r/pa/ei/bgn/2875.htm

${ }^{5} \mathrm{http}: / / \mathrm{www}$. state.gov/r/pa/ei/bgn/2875.htm

${ }^{6} \mathrm{http}: / / \mathrm{www} \cdot \mathrm{state} . \mathrm{gov} / \mathrm{r} / \mathrm{pa} / \mathrm{ei} / \mathrm{bgn} / 3430$

${ }^{7} \mathrm{http}: / / \mathrm{www} \cdot$ state.gov/r/pa/ei/bgn/3407.htm

${ }^{8}$ Human Development Reports: http://hdr.undp.org/en/statistics/

${ }^{9}$ Calculation based upon data provided by eurostat (2008) for students in tertiary education, available at: http://epp.eurostat.ec.europa.eu/statistics_explained/images/4/46/Students_in_tertiary_education\%2C_2008_\% $281 \% 29$.png

\section{Literature review}

The existence of multiple definitions of societal culture, as well as of multiple and often conflicting models of theories about it made some researchers speak 
about a "culture theory jungle" (Nardon/Steers 2009). What is common to this "jungle" is the concept of values. According to Rokeach (1973: 5), a value is an "enduring belief that a specific mode of conduct or end-state of existence is personally or socially preferable to an opposite or converse mode of conduct or end-state of existence". As accepted by most of the researchers, values express the propensity of the members of society to judge what is good or bad, what should and should not be done, what is natural or not natural, rational or irrational, and so on (Schwartz 1992; Hofstede 1997).

Starting from Kluckhohn and Stodtbeck's (1961) anthropological theory on five value orientations, Hofstede (1980, 2001), Trompenaars (1993), Trompenaars and Hampden-Turner (1998), Schwartz (1992), House et al. (2004) (among others) focused on universal cultural dimensions and developed different models of societal culture.

Having a psychological/behavioural foundation which assumes that shared values are incorporated in behaviours, policies and practices, the GLOBE study (House et al. 2004) differs from other approaches in three respects. First, it measures culture using nine cultural dimensions (details about GLOBE's cultural dimensions to be found in Čater, Lang and Szabo's introduction article in this JEEMS special issue). Second, to find out value change trends, GLOBE distinguishes between cultural practices and values (expectations). Of course, this distinction is a relative one, because philosophically speaking, a good practice is a learned value. So, any good practice was at some point a value, an expectation, a model. In other words, shared values become good future practices. Third, the GLOBE research focused on identifying and understanding the influence of societal culture on leadership prototypes (House et al. 2004: 669-719).

Some studies on societal culture approached the European countries. For instance, Western and Eastern European values at the beginning of the 1990s were compared by Broek and Moor (1994), based on the hypothesis that Eastern Europeans should be more traditionalistic and less individualistic than Western Europeans (using data from the European Values Survey 1990-91).

Differences between Eastern and Western Europe, as well as between Bulgaria, Russia and Georgia on the one hand and the rest of Eastern Europe on the other hand, were approached by Schwartz and Bardi (1997) with samples of teachers and students, using the Schwartz value survey.

Treating CEE countries as one group, Schwartz, Bardi and Bianchi (2000) used empirical data to assess value changes after the collapse of communism, based upon the hypothesis that the values should move away from security, conformity and tradition toward stimulation, self-direction, hedonism, universalism, benevolence and achievement. Due to the threat of punishment for behaving differently than the rules demanded, the initiative and propensity toward risk 
were (usually) avoided in former communist settings, people valuing safety, accepting the distribution of roles (power) and resources, lacking Performance Orientation (personal achievement was not of interest under "collectivistic" distribution of results and promotion based on political decision).

Hampden-Turner and Trompenaars (2000) researched a CEE cluster comprising Bulgaria, the Czech Republic, Greece, Hungary, Poland, Russia and Yugoslavia and found that the cluster is high in individualism and has no achievement orientation.

Gupta, Hanges and Dorfman (2002) found, as a result of the GLOBE research, another CEE cluster which includes Albania, Georgia, Greece, Hungary, Poland, Russia and Slovenia. Although these countries come from two continents, with different economic, cultural, historical and religious foundations, they were reported to share high In-group Collectivism and Power Distance, low Uncertainty Avoidance and Future Orientation. As known, the cluster average score gives a "helicopter view" on the whole sample, hiding potential differences between the countries. For instance, two countries from the mentioned sample and of interest in our study (Poland and Slovenia) displayed differences from the cluster score for many cultural practices and values. Poland was found to have the highest score on Collectivism I (Institutional Collectivism: 4.53), the second highest score on Gender Egalitarianism (4.02) and the second lowest score on Future Orientation (3.11) in practice, while Slovenia showed the highest mean in Assertiveness (3.99). At the expectations level, Slovenia displayed the highest score (6.41) and Poland the second highest one (6.12) in Performance Orientation and vice versa for Collectivism II (Ingroup Collectivism; Poland the highest score: 5.74, Slovenia the second highest: 5.71) (Bakacsi et al. 2002: 76).

Accepting that values "high in centrality, pervasive, and supported by powerful sanctions and high consensus" (Williams 1979: 34) are resistant to change, we are also aware that they change under the action of different factors, such as fundamental change of the socio-economic and political system, people's life cycle (Mead 1998; Helson et al. 2002), change of power holders generation, or exposure to similar products, services, knowledge, information, media and education as in today's increasingly connected world. As Fang notices, a culture learns from its predecessors the old traditions but also from its dynamic interactions with other cultures to give birth to new traditions, new beliefs and new behaviours (Fang 2005-2006). Evidence of culture change can be expected at the level of young people first, who are more educated and open to new, postmodernistic values (Inglehart/Welzel 2005).

Using Hofstede's model of five cultural dimensions for a comparison of students and managers from Slovenia (among other Slavic countries), Prašnikar, Pahor and Vidmar Svetlik (2008) found out that signs of culture change: The students 
are more willing to take risks, have less emotional resistance to change and are less individualistic than the managers.

Based upon GLOBE methodology, Keating, Martin and Szabo (2002) compared students with middle managers from Austria and Ireland and revealed that the country effect appeared to be stronger than the cohort/age effect. Strong convergence was found for Gender Egalitarianism and Power Distance.

Following GLOBE's theoretical basis in culture, leadership and socialisation theory, the GLOBE Student project's first results (1737 subjects from five CEE countries, $47.5 \%$ with studies in business economics, $43.6 \%$ in engineering) show significant differences in students' perceptions of societal cultural practices and their cultural expectations (Čater/Lang 2011). The present study extends the discussions on convergence/divergence in engineering and business students' societal culture perceptions and expectations, examining seven CEE countries.

\section{Methodology}

The population of interest was defined as engineering and business students (compare the article by Čater, Lang and Szabo in this special issue for background and details about the sample, questionnaires and scales). The surveys were administered in individual participating countries in either 2008 or the first half of 2009. The collected empirical data was processed with SPSS 17. A descriptive statistical analysis was carried out for the whole cluster of countries. Paired-samples t-test ( 0.05 significance threshold) was employed to test the statistical significance in mean values of the differences between societal practices ("as is" variables) and societal values ("as should be" variables) in the sample. One-way ANOVA was used to test for differences in perceptions and expectations between the seven countries. Normal distribution (KolmogorovSmirnov test) and homogeneity of variances (Levene, Welch) in mean values were employed and homogeneous subsets were determined using Tukey and Games-Howell tests with alpha $=0.05$.

\section{Findings}

Average cultural characteristics of CEE students from culture related perceptions and expectations perspectives

Mean values and rank of cultural practices and expectations are displayed in Table 2. As seen, the "average" student in the investigated sample perceives his/her society as practicing high Power Distance (highest mean value) and Ingroup and Institutional Collectivism, respectively, as well as low Future Orientation, Gender Orientation and Humane Orientation (lowest score). At expectation level, the average student desires to live in a society characterized by high Performance Orientation (highest mean score), In-group Collectivism 
and Humane Orientation, and low Assertiveness and Power Distance (lowest mean score). Obviously, the values have an almost completely reversed hierarchy compared to the practices. The only exception is In-group Collectivism, which preserves its second place.

Table 2: Descriptive statistics for 7-country CEE cluster

\begin{tabular}{|c|c|c|c|c|c|c|}
\hline & $\mathbf{N}$ & Minimum & Maximum & Mean & $\begin{array}{l}\text { Std. } \\
\text { Dev. }\end{array}$ & Rank \\
\hline \multicolumn{7}{|l|}{ Societal Practices } \\
\hline Uncertainty Avoidance & 2352 & 1 & 7 & 4.23 & .971 & 4 \\
\hline Future Orientation & 2352 & 1 & 7 & 3.98 & 1.026 & 7 \\
\hline Power Distance & 2352 & 2 & 7 & 5.26 & .871 & 1 \\
\hline $\begin{array}{l}\text { Collectivism I } \\
\text { (Institutional) }\end{array}$ & 2349 & 1 & 7 & 4.26 & .874 & 3 \\
\hline Humane Orientation & 2351 & 1 & 6 & 3.65 & .883 & 9 \\
\hline $\begin{array}{l}\text { Performance } \\
\text { Orientation }\end{array}$ & 2351 & 1 & 7 & 4.09 & 1.040 & 6 \\
\hline $\begin{array}{l}\text { Collectivism II (In- } \\
\text { group) }\end{array}$ & 2351 & 2 & 7 & 4.69 & .954 & 2 \\
\hline Gender Egalitarianism & 2351 & 1 & 6 & 3.93 & .739 & 8 \\
\hline Assertiveness & 2352 & 1 & 7 & 4.16 & .905 & 5 \\
\hline \multicolumn{7}{|l|}{ Societal Values } \\
\hline Uncertainty Avoidance & 2348 & 1 & 7 & 4.60 & .874 & $5-6$ \\
\hline Future Orientation & 2348 & 1 & 7 & 4.83 & .972 & 4 \\
\hline Power Distance & 2348 & 1 & 7 & 2.69 & .890 & 9 \\
\hline $\begin{array}{l}\text { Collectivism I } \\
\text { (Institutional) }\end{array}$ & 2348 & 1 & 7 & 4.60 & .834 & $5-6$ \\
\hline Humane Orientation & 2348 & 1 & 7 & 5.26 & .783 & 3 \\
\hline $\begin{array}{l}\text { Performance } \\
\text { Orientation }\end{array}$ & 2348 & 1 & 7 & 5.84 & .788 & 1 \\
\hline $\begin{array}{l}\text { Collectivism II (In- } \\
\text { group) }\end{array}$ & 2348 & 1 & 7 & 5.61 & .920 & 2 \\
\hline Gender Egalitarianism & 2348 & 2 & 7 & 4.51 & .633 & 7 \\
\hline Assertiveness & 2348 & 1 & 7 & 3.51 & .942 & 8 \\
\hline
\end{tabular}


Significant differences between the perceived and expected cultural dimensions in the sample

Statistically significant differences between the cluster perception on practices and values are shown in Table 3. As seen, the sample records the highest significant differences between practices and expectations (decreasing order) for Power Distance, Performance Orientation and Humane Orientation. There is an excess of Power Distance (practice vs. expectations $=92.154$; sig. $=0.000$ ) in the whole sample, and a deficit in Performance Orientation (-64.932; sig. = 0.000) and Humane Orientation (-68.228; sig. $=0.000)$.

Table 3: Significant differences between practices and values (whole sample)

\begin{tabular}{|l|l|l|c|c|c|c|c|c|}
\hline & Mean & $\begin{array}{c}\text { Std. } \\
\text { Dev. }\end{array}$ & $\begin{array}{c}\text { Std. Err. } \\
\text { Means }\end{array}$ & Lower & Upper & t & Sig. \\
\hline Pair 1 & U. A. & -.365 & 1.403 & .029 & -.422 & -.309 & -12.622 & .000 \\
\hline Pair 2 & F. O. & -.846 & 1.469 & .030 & -.905 & -.786 & -27.907 & .000 \\
\hline Pair 3 & P. D. & 2.567 & 1.350 & .028 & 2.513 & 2.622 & 92.154 & .000 \\
\hline Pair 4 & Coll. & -.342 & 1.260 & .026 & -.394 & -.291 & -13.166 & .000 \\
\hline I. & & & & & & & \\
\hline Pair 5 & H. O. & -1.610 & 1.143 & .024 & -1.656 & -1.564 & -68.228 & .000 \\
\hline Pair 7 & $\begin{array}{l}\text { Coll. } \\
\text { II. }\end{array}$ & -1.744 & 1.301 & .027 & -1.796 & -1.691 & -64.932 & .000 \\
\hline Pair 8 & G. E. & -.582 & .865 & .018 & -.617 & -.547 & -32.622 & .000 \\
\hline Pair 9 & Ass. & .650 & 1.390 & .029 & .594 & .706 & 22.663 & .000 \\
\hline
\end{tabular}

Note: 95\% confidence interval of the difference.

Legend: U. A. = Uncertainty Avoidance; F. O. = Future Orientation; P. D. = Power Distance; Coll. I = Collectivism I (Institutional); H. O. = Humane Orientation; P. O. = Performance Orientation; Coll. II = Collectivism II (In-group); G. E. = Gender Egalitarianism; Ass. = Assertiveness.

Country of origin as a factor explaining the differences in perceptions and expectations of students from different countries

Squared Eta test was performed to check the proportion of variance in the mean scores associated with the country of origin. It shows that in the case of practices, the country of origin more strongly relates with Uncertainty Avoidance (32.6\%), In-group Collectivism (29.3\%) and Future Orientation (22.9\%), and less strongly with the variance of perceptions concerning Gender Egalitarianism (2.7\%), Performance Orientation (7.7\%) and Institutional Collectivism (9.1\%). The proportion of variance in the mean scores of the other 
three cultural practices associated with the country of origin is in between the cases mentioned above.

The same test (Squared Eta) shows that the country of origin does not really matter for most of the cultural expectations (ranging from 1\% to 6.6\%), except for Uncertainty Avoidance (11.5\%) and Assertiveness (17.5\%). It seems that other independent (categorical) variables might explain the variance in the expectations mean scores (i.e. gender, religion, major field of study etc.).

\section{Distinctive subsets are formed inside the CEE cluster}

To find out if distinctive subsets along the cultural dimensions are formed inside the CEE cluster, data about country specific statistics is provided in the following. Table 4 and Figure 1 display the mean values of cultural practices and, respectively, expectations in each country in the sample.

Table 4: Cultural practices in the sample

\begin{tabular}{|c|c|c|c|c|c|c|c|c|c|c|}
\hline \multicolumn{2}{|l|}{ Country } & \multirow{2}{*}{$\begin{array}{l}\text { U. A. } \\
4.89\end{array}$} & \multirow{2}{*}{$\begin{array}{c}\text { F. } 0 . \\
4.67\end{array}$} & \multirow{2}{*}{$\begin{array}{l}\text { P. D. } \\
5.09\end{array}$} & \multirow{2}{*}{$\begin{array}{c}\text { Coll. } \\
\text { I } \\
4.50\end{array}$} & \multirow{2}{*}{$\begin{array}{c}\text { H. } \\
\text { O. }\end{array}$} & \multirow{2}{*}{$\begin{array}{l}\text { P. } 0 . \\
4.42\end{array}$} & \multirow{2}{*}{$\begin{array}{c}\text { Coll. } \\
\text { II }\end{array}$} & \multirow{2}{*}{$\begin{array}{c}\text { G. } \\
\text { E. } \\
3.93\end{array}$} & \multirow{2}{*}{$\begin{array}{l}\text { Ass. } \\
4.66\end{array}$} \\
\hline Germany & Mean & & & & & & & & & \\
\hline & $\begin{array}{l}\text { Std. } \\
\text { Dev. }\end{array}$ & .812 & .802 & .759 & .892 & .709 & .973 & .721 & .702 & .770 \\
\hline \multirow[t]{2}{*}{ Austria } & Mean & 5.20 & 4.78 & 4.84 & 4.29 & 3.84 & 4.51 & 4.11 & 3.75 & 4.40 \\
\hline & $\begin{array}{l}\text { Std. } \\
\text { Dev. }\end{array}$ & .713 & .917 & .804 & .820 & .804 & .964 & .737 & .696 & .826 \\
\hline \multirow[t]{2}{*}{ Romania } & Mean & 3.49 & 3.44 & 5.81 & 3.78 & 3.83 & 3.66 & 5.13 & 3.99 & 3.51 \\
\hline & $\begin{array}{l}\text { Std. } \\
\text { Dev. }\end{array}$ & .799 & .847 & .765 & .828 & .872 & .999 & .779 & .674 & .796 \\
\hline \multirow[t]{2}{*}{ Slovenia } & Mean & 4.19 & 3.79 & 5.03 & 4.04 & 3.97 & 4.05 & 5.22 & 4.13 & 4.24 \\
\hline & $\begin{array}{l}\text { Std. } \\
\text { Dev. }\end{array}$ & .799 & 1.128 & .885 & .907 & .773 & 1.036 & .951 & .845 & .977 \\
\hline \multirow{2}{*}{$\begin{array}{l}\text { Slovak } \\
\text { Republic }\end{array}$} & Mean & 4.02 & 3.88 & 5.27 & 4.43 & 3.72 & 4.03 & 4.77 & 3.97 & 4.38 \\
\hline & $\begin{array}{l}\text { Std. } \\
\text { Dev. }\end{array}$ & .844 & .805 & .790 & .812 & .920 & 1.025 & .787 & .743 & .891 \\
\hline \multirow{2}{*}{$\begin{array}{l}\text { Czech } \\
\text { Republic }\end{array}$} & Mean & 4.04 & 3.89 & 5.29 & 4.41 & 3.46 & 4.22 & 4.97 & 3.97 & 4.02 \\
\hline & $\begin{array}{l}\text { Std. } \\
\text { Dev. }\end{array}$ & .838 & .807 & .812 & .760 & .761 & .929 & .857 & .705 & .791 \\
\hline
\end{tabular}




\begin{tabular}{|l|l|c|c|c|c|c|c|c|c|c|}
\hline Poland & Mean & 4.00 & 3.55 & 5.27 & 4.48 & 3.67 & 3.86 & 4.84 & 3.75 & 4.10 \\
\cline { 2 - 10 } & $\begin{array}{l}\text { Std. } \\
\text { Dev. }\end{array}$ & .768 & 1.008 & .941 & .819 & .976 & 1.079 & .790 & .755 & .763 \\
\hline \multirow{2}{*}{ Cluster } & Mean & 4.23 & 3.98 & 5.26 & 4.26 & 3.65 & 4.09 & 4.69 & 3.93 & 4.16 \\
\cline { 2 - 10 } & $\begin{array}{l}\text { Std. } \\
\text { Dev. }\end{array}$ & .971 & 1.026 & .871 & .874 & .883 & 1.040 & .954 & .739 & .905 \\
\hline
\end{tabular}

Legend: U. A. = Uncertainty Avoidance; F. O. = Future Orientation; P. D. = Power Distance; Coll. I = Collectivism I (Institutional); H. O. = Humane Orientation; P. O. = Performance Orientation; Coll. II = Collectivism II (In-group); G. E. = Gender Egalitarianism; Ass. = Assertiveness.

The data shows that Austria is the group leader in three cases: Uncertainty Avoidance, Future Orientation and Performance Orientation; Slovenia in the other three cases: Humane Orientation, In-group Collectivism and Gender Egalitarianism; Germany in Institutional Collectivism and Assertiveness, while Romania displays the highest mean score for Power Distance. Romania records the lowest scores for all dimensions related to the market economy: Uncertainty Avoidance, Future Orientation, Performance Orientation, Assertiveness and Institutional Collectivism.

Data concerning the expected values show that the Romanian sample would like to change the way the society behaves. It has the highest scores in five cases: Uncertainty Avoidance (5.10), Future Orientation (5.23), Institutional Collectivism (4.94), Humane Orientation (5.41) and In-group Collectivism (5.70). Slovenia records the highest mean score on Power Distance (2.94) and Assertiveness (4.09). 
Figure 1: Cultural expectations in the sample

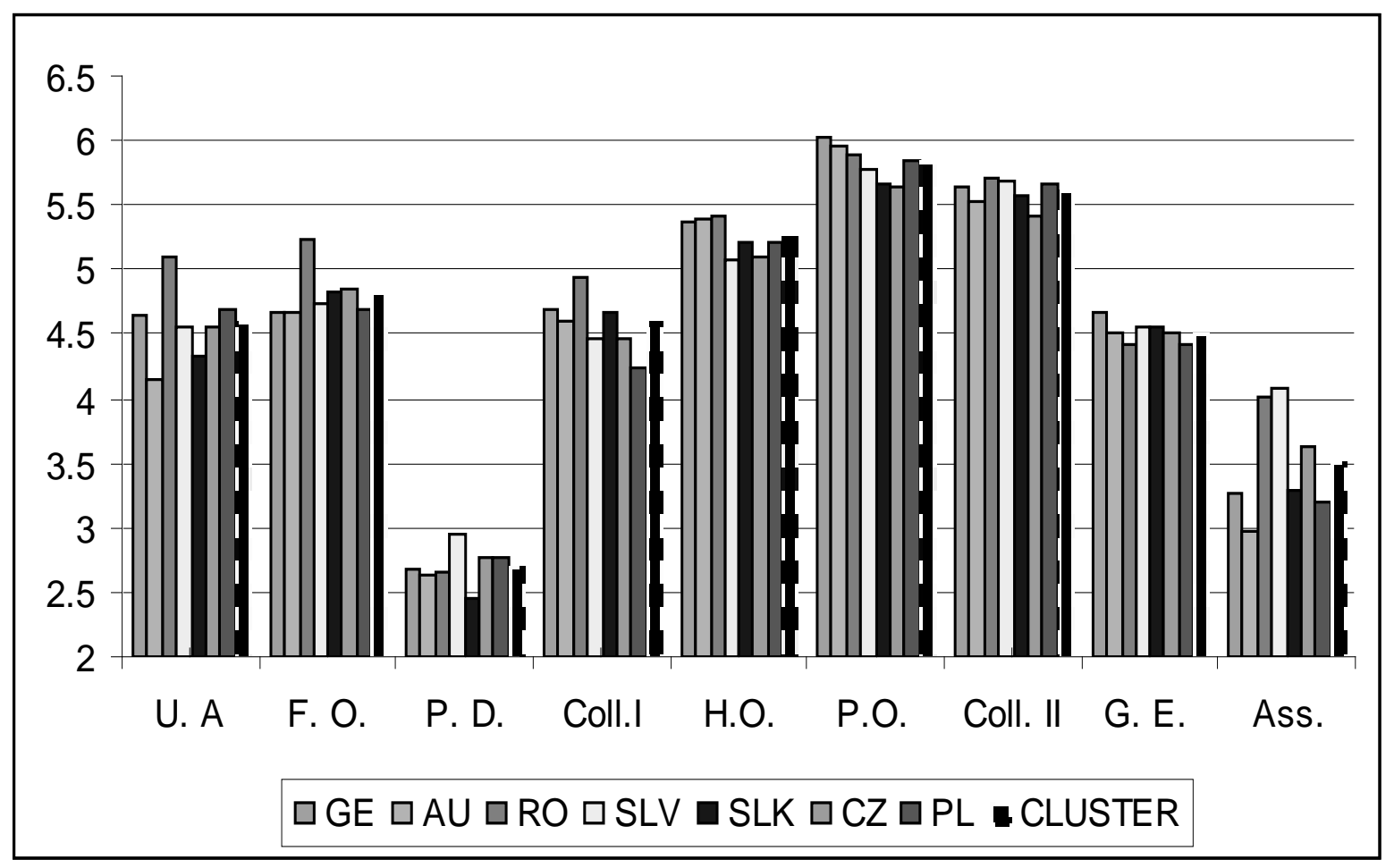

There is a statistically significant difference between countries as determined by one-way ANOVA (both for practices and expectations). Normal distribution (Kolmogorov-Smirnov test) and homogeneity of variances in countries' mean value were tested. As for all practices and values a K-S test yielded significance levels lower than 0.05, we might assume that the distribution is normal. As the assumption of homogeneity of variances was broken (Levene test), Welch version of $F$ ratio was determined. The test was highly significant (sig. values < .005 ). Therefore, we can say that there is a significant effect of the country of origin on the mean values.

To find out where the difference between countries lies, we made multiple comparisons (95\% confidence interval) with Tukey and Games Howell post hoc tests. Both tests showed statistically significant differences in performing multiple comparisons. Due to space constraints we can only provide the highest differences recorded for each practice and expectation dimension, respectively (Table 5). Romania seems to be a specific (unique) case in the sample, recording the highest significant differences in six out of nine cultural practices and cultural expectations, respectively. 
Table 5: Highest significant mean differences in the sample

\begin{tabular}{|c|c|c|}
\hline \multirow{2}{*}{$\begin{array}{l}\text { Cultural } \\
\text { Dimension }\end{array}$} & \multicolumn{2}{|c|}{ Highest Significant Mean Difference } \\
\hline & Practices & Values \\
\hline $\begin{array}{l}\text { Uncertainty } \\
\text { Avoidance }\end{array}$ & $\begin{array}{l}\text { Austria-Romania (1.70; sig. = } \\
0.000)\end{array}$ & $\begin{array}{l}\text { Austria-Romania (0.96; sig. = } \\
0.000)\end{array}$ \\
\hline $\begin{array}{l}\text { Future } \\
\text { Orientation }\end{array}$ & $\begin{array}{l}\text { Austria-Romania (1.35; sig. = } \\
0.000)\end{array}$ & $\begin{array}{l}\text { Austria-Romania (0.58; sig. = } \\
0.000)\end{array}$ \\
\hline Power Distance & $\begin{array}{l}\text { Austria-Romania (0.96; sig. = } \\
0.000)\end{array}$ & $\begin{array}{l}\text { Slovakia-Slovenia (0.5; sig. = } \\
0.000)\end{array}$ \\
\hline $\begin{array}{l}\text { Collectivism I } \\
\text { (Institutional) }\end{array}$ & $\begin{array}{l}\text { Germany-Romania (0.72; sig. = } \\
0.000)\end{array}$ & $\begin{array}{l}\text { Poland-Romania (0.76; sig. = } \\
0.000)\end{array}$ \\
\hline $\begin{array}{l}\text { Humane } \\
\text { Orientation }\end{array}$ & $\begin{array}{l}\text { Germany-Slovenia (0.92; sig. = } \\
0.000)\end{array}$ & $\begin{array}{l}\text { Romania-Slovenia (0.33; sig. = } \\
0.000)\end{array}$ \\
\hline $\begin{array}{l}\text { Performance } \\
\text { Orientation }\end{array}$ & $\begin{array}{l}\text { Austria-Romania (0.85; sig. = } \\
0.000)\end{array}$ & $\begin{array}{l}\text { Germany-Czech Rep. (0.38; sig. = } \\
0.000)\end{array}$ \\
\hline $\begin{array}{l}\text { Collectivism II } \\
\text { (In-group) }\end{array}$ & $\begin{array}{l}\text { Germany-Slovenia (1.50; sig. = } \\
0.000)\end{array}$ & $\begin{array}{l}\text { Romania-Czech Rep. (0.28; sig. = } \\
0.000)\end{array}$ \\
\hline $\begin{array}{l}\text { Gender } \\
\text { Egalitarianism }\end{array}$ & $\begin{array}{l}\text { Austria-Slovenia (0.38; sig. = } \\
0.000)\end{array}$ & $\begin{array}{l}\text { Germany-Romania (0.24; sig. = } \\
0.000)\end{array}$ \\
\hline Assertiveness & $\begin{array}{l}\text { Germany-Romania (1.14; sig. = } \\
0.000 \text { ) }\end{array}$ & $\begin{array}{l}\text { Austria-Slovenia (1.11; sig. }= \\
0.000)\end{array}$ \\
\hline
\end{tabular}

The homogeneous subsets (for alpha $=0.05$ ) resulting for each of the cultural dimensions (practices and values) are displayed in Table 6.

Table 6: Homogeneous subsets in CEE cluster (Tukey test results)

\begin{tabular}{|l|l|l|}
\hline $\begin{array}{l}\text { Homogeneous Subsets: } \\
\text { Practices }\end{array}$ & $\begin{array}{l}\text { Social } \\
\text { Culture } \\
\text { Dimensions }\end{array}$ & Homogeneous Subsets: Values \\
\hline $\begin{array}{l}\text { 1. Poland, Slovakia, Czech } \\
\text { Republic }\end{array}$ & $\begin{array}{l}\text { Uncertainty } \\
\text { Avoidance }\end{array}$ & $\begin{array}{l}\text { 1. Slovenia, Czech Republic, Germany, } \\
\text { Poland }\end{array}$ \\
\hline $\begin{array}{l}\text { 1. Poland, Romania } \\
\text { 2. Slovenia, Slovakia, Czech } \\
\text { Republic }\end{array}$ & Future & $\begin{array}{l}\text { 1. Austria, Germany, Poland, Czech } \\
\text { Republic, Slovenia, Slovakia }\end{array}$ \\
3. Germany, Austria & & \\
\hline
\end{tabular}




\begin{tabular}{|l|l|l|}
\hline $\begin{array}{l}\text { 1. Slovenia, Germania } \\
\text { 2. Slovakia, Poland, Czech } \\
\text { Republic }\end{array}$ & $\begin{array}{l}\text { Power } \\
\text { Distance }\end{array}$ & $\begin{array}{l}\text { 1. Austria, Romania, Germany, Poland, } \\
\text { Czech Republic }\end{array}$ \\
\hline $\begin{array}{l}\text { 1. Austria, Czech Republic, } \\
\text { Slovakia } \\
\text { 2.Poland, Germany }\end{array}$ & $\begin{array}{l}\text { Collectivism I } \\
\text { Institutional) }\end{array}$ & $\begin{array}{l}\text { 1. Slovenia, Czech Republic, Austria } \\
\text { 2. Slovakia, Germany }\end{array}$ \\
\hline $\begin{array}{l}\text { 1. Poland, Slovakia, Romania, } \\
\text { Austria }\end{array}$ & $\begin{array}{l}\text { Humane } \\
\text { Orientation }\end{array}$ & $\begin{array}{l}\text { 1. Slovenia, Czech Republic, Slovakia, } \\
\text { Poland }\end{array}$ \\
\hline $\begin{array}{l}\text { 1. Poland, Slovakia, Slovenia } \\
\text { 2. Germany, Austria }\end{array}$ & $\begin{array}{l}\text { Performance } \\
\text { Orientation }\end{array}$ & $\begin{array}{l}\text { 1. Czech Republic, Slovakia, Slovenia } \\
\text { 2. Poland, Romania, Austria }\end{array}$ \\
\hline $\begin{array}{l}\text { 1.Slovakia, Poland } \\
\text { 2.Germany, Austria }\end{array}$ & $\begin{array}{l}\text { Collectivism II } \\
\text { (In-group) }\end{array}$ & $\begin{array}{l}\text { 1. Czech Republic, Austria, Slovakia } \\
\text { 2. Germany, Poland, Slovenia, Romania }\end{array}$ \\
\hline $\begin{array}{l}\text { 1. Slovakia, Poland } \\
\text { 2. Romania, Slovenia }\end{array}$ & $\begin{array}{l}\text { Gender } \\
\text { Egalitarianism }\end{array}$ & $\begin{array}{l}\text { 1. Romania, Poland, Czech Republic, } \\
\text { Austria }\end{array}$ \\
\hline $\begin{array}{l}\text { 1. Czech Republic, Poland } \\
\text { 2. Slovenia, Slovakia, Austria }\end{array}$ & Assertiveness & $\begin{array}{l}\text { 1. Poland, Germany, Slovakia } \\
\text { 2. Romania, Slovenia }\end{array}$ \\
\hline
\end{tabular}

As seen, homogeneous subsets differ along cultural dimensions on the one hand, and between practices and expectations on the other hand. The biggest group for practices concerns Humane Orientation and comprises Poland, Slovakia, Romania and Austria (range of mean values: 3.67 - 3.84). In the case of expectations, the biggest homogeneous group concerns Future Orientation and comprises six countries: Austria, Germany, Poland, the Czech Republic, Slovenia and Slovakia (range of mean values: 4.66 - 4.86). This last result might be taken as a sign of convergence among the next generation of managers as far as time orientation is concerned.

\section{Discussions}

The main objective of this article is to examine the profile of future managers (students of business and engineering) from the perspective of their perceptions and expectations about societal culture dimensions. The sample comes from a mixture of seven European countries with different characteristics which, at the same time, share some common attributes. On the one hand, Europe is becoming more culturally diverse and cultural sensitivity and intercultural dialogue seem to play a critical role in developing successful cooperation and mutually beneficial growth. On the other hand, the research results show in respect of the examined students that, undoubtedly, in many aspects we deal with some 
common characteristics of young Europeans, who make up a group known as "Generation Y".

\section{Average cultural characteristics of the students in the joint sample of seven examined countries}

Looking at the joint sample values, the average student desires high Performance Orientation, Humane Orientation and In-group Collectivism for the future.

Societies that score higher on Performance Orientation tend to reward individual achievement, value training and development, bonuses and financial rewards and view feedback as necessary for improvement (compare Table 12.1 in House et al. 2004: 245). Born between the 1980s and the late 1990s, Generation Y graduates (also known as the Millennials) are in their 20s and 30s, already in or just entering the labour market, taking their place in an increasingly multigenerational workplace ${ }^{9}$. There are few common traits defining the Generation $\mathrm{Y}$ to be found in the literature. One of these traits emphasises that the Generation Y is achievement-oriented (Hentley 2006: 10). It wants to be judged on individual outcome and craves attention in the form of feedback and guidance (Kapetanovic 2010: 47).

Characteristics of societies that have a high Humane Orientation include the following aspects: other individuals are important (i.e. family and friends), people are motivated primarily by the need of belonging and affiliation and are urged to be sensitive to all forms of racial discrimination (based on Table 18.1 in House et al. 2004: 570). The desire for future high Humane Orientation in the examined group of students confirms some other qualities of the Generation $\mathrm{Y}$ presented in the literature. It has been emphasised that Millennials want to be included and involved (Hansford 2002: 50), are concerned about societal and environmental responsibilities (Tracz 2009: 157), are well familiar with globalisation and embrace diversity (Sujansky 2010: 14).

In-group Collectivism practices and values are positively related to the strength of family ties (House et al. 2004: 454). The Yers are family-centric and willing to trade high pay for fewer billable hours, flexible schedules and a better work/life balance (Newton 2005: 41).

\footnotetext{
${ }^{9}$ The term "generation" has been defined in a number of ways. One of the most accepted definitions refers to a generation as "a group of people or cohorts who share birth years and experiences as they move through time together" (Kupperschmidt 2000: 66). Although there is no consensus over the exact birth dates that define each generation, there is agreement on three distinct generations in the workforce today, including:

Boomers: born between 1940 and 1960,

Xers: born between 1960 and 1980,

Generation Y, or the Millennials: born between 1980 and the late 1990s; to be followed by

Generation Z, which is projected to begin entering the workplace around 2020 (Meuse/Mlodzik 2010: 51).
} 


\section{Country of origin as factor explaining the differences in perceptions and expectations of students from different countries}

According to our findings, country of origin seems to have stronger influence on the variance of perceptions (practices) for Uncertainty Avoidance, In-group Collectivism and Future Orientation. It has little influence on most of the cultural expectations (values), except Uncertainty Avoidance and Assertiveness.

In the case of Uncertainty Avoidance, it is interesting that countries like Austria and Germany display lower mean score in values in this dimension in comparison to practices (in particular Austria) and all other countries record higher mean values (in particular Romania).

A way of thinking about Uncertainty Avoidance relates to the extent to which ambiguous situations are felt as threatening, i.e. about the extent to which deliberate measures (such as making and enforcing rules and procedures) are taken to reduce ambiguity. After the transition from centrally-planned to marketbased economies, former communist CEE countries experienced significant changes in the world of work. People had to face unemployment, job insecurity and the loss of regular income. More than that, the recent economic crisis brought new challenges for all countries, including CEE countries. They have been confronted with an increasing intensity of changes. Consequently, people have developed a more cautious, rational and less risk-based way of dealing with everyday situations in life. Under these circumstances there is no doubt that young East Europeans perceive today's world as unpredictable and largely money-driven, so they are ready to work hard and gain additional education to achieve tangible results in their work.

Based on our findings country of origin seems to have a stronger influence on the variance of practices for In-group Collectivism - see a homogeneous subset for Collectivism II (values). According to House et al. (2004: 486, see Table 16.11h) In-group Collectivism practices and values are positively related to the extent to which family is important in life and to the strengh of family ties.

Looking at the importance of different spheres in life according to the EVS, it is striking that family is extremely important to all Europeans - but there are also some differences between countries in the intensity of considering family as 'very important' in life.

In all examined countries (with the exception of Romania), students wish a lower level of Assertiveness in the future (the strongest drop is observed in the case of Germany and Austria). Lower Assertiveness corresponds with such work-related value preferences as not too much pressure, good hours, generous 
holidays and a job that is family friendly ${ }^{10}$. In terms of the last aspect, particular preferences can be seen in Romania, Slovakia, Poland and Slovenia - a homogeneous subset in the CEE cluster for Asseriveness (values).

Our article aims at exploring the motions of convergence and divergence in respect of societal cultural practices and values within the seven examined countries. As researchers assert, in respect of the younger generation, members of a particular group often have more in common with each other across national boundaries than with other groups within their own national culture (Keating et al. 2002: 638). On the other hand, the influence of social and cultural environments must not be underestimated.

It is very difficult to find direct, unambiguous answers that explain differences between examined countries in regard to societal cultural practices and values. There are too many variables of influence that need to be considered. One possible approach to explore our findings could be to confront them with the results of the European Values Study, being aware that comparing different samples of research findings might be problematic and requires further investigation. Nonetheless, we believe that relating the GLOBE Student findings to some results of the EVS offers additional insights into relevant issues and may help better understand future managers' cultural perceptions and expectations in the seven examined countries.

\section{Conclusions and future research}

The present study is of exploratory nature, thus, we limit our conclusions to the preliminary findings related to the proposed research questions.

The average student in the sample perceives high Power Distance, In-group Collectivism and, respectively, Institutional Collectivism. For the future the students desire high Performance Orientation, In-group Collectivism and Humane Orientation. Concerning the differences between practices and values, statistically significant differences are recorded for Power Distance (desire to decrease) and Humane Orientation (desire to increase).

Related to the influence of the country of origin on the variance of perceptions (practices) and expectations (values) it seems that the country of origin relates stronger with Uncertainty Avoidance, In-group Collectivism and Future Orientation in the case of practices. The country of origin has little influence on most of the cultural expectations (except Uncertainty Avoidance and Assertiveness).

\footnotetext{
${ }^{10}$ The EVS (European Values Study) listed seventeen benefits of work and workplace about which participants of the research gave their opinions. To the best of our knowledge EVS is the most comprehensive data source on basic values held by Europeans. It expresses the wide range of preferences, attitudes and beliefs in the most important areas of life such as religion, family, politics, economics, work and morality. It is widely accepted as a large-scale, cross-national research project on fundamental values and has been conducted in almost all European countries using a standardized, common questionnaire (www.europeanvaluesstudy.eu).
} 
In terms of cultural practices, the biggest group is formed around Humane Orientation and comprises Poland, Slovakia, Romania and Austria. In the case of cultural expectations, the biggest homogeneous group is formed around Future Orientation and comprises Austria, Germany, Poland, the Czech Republic, Slovenia and Slovakia.

We are aware that our study has limitations which include the assumption that business and engineering students will be a core part of the future managers' population, the small number of CEE countries under study (limiting the possibility of generalising the results), the unequal size of countries' samples and even the location of German respondents.

In spite of these limitations, we still believe that our research findings offer certain insights into the relevant issues. These insights might be useful for researchers, employers, universities, governments and students. The employers (national or multinational) receive an image of the average cultural characteristics of future managers. On this basis they can design development programs for present managers, according to the trend expressed by the students' population. Universities and governments could use our findings for designing strategies aiming at preparing students for the market of the next elites in economy, for creating and developing a leadership culture among young generations. Students themselves could take into account our findings for clarifying their options for own business or management positions.

Further research should be focused on the study of cultural practices and value systems in several directions. One should study possible differences in respondents relevant perceptions based on their demographic variables (for example gender, field of study, level of study etc.). Comparisons of our research findings with the research results of a wider sample of CEE countries will be fruitful for better explanations of our empirical findings. Our findings could also be compared with the GLOBE project's managerial findings for the CEE region. 


\section{References}

Bakacsi, G./Takács, S./Karácsonyi A./Imrek, V. (2002): Eastern European cluster: Tradition and transition, in: Journal of World Business, 37, 1, 69-80.

Broek, A. van den/Moor, R. de (1994): Eastern Europe after 1989, in: Ester, P./Halman, L./Moor, R. de (eds.): The individualizing society: Value change in Europe and North America. Tilburg: Tilburg University Press, 197-228.

Čater, T./Lang, R. (eds.) (2011): Values and leadership expectations of future managers from transforming societies, Organisationswissenschaftliche Schriftenreihe der TU Chemnitz, No. 16, August 2011. Chemnitz: Chemnitz University of Technology. (http://www.tuchemnitz.de/wirtschaft/bwl5/forschung/schriften/doc/16.pdf)

Fang, T. (2005-2006): From “onion” to "ocean": Paradox and change in national cultures, in: International Studies of Management, 35, 4, 71-90.

Gupta, V./Hanges, P.J./Dorfman, P.W. (2002): Cultural clusters: Methodology and findings, in: Journal of World Business, 37, 1, 11-15.

Hampden-Turner, Ch./Trompenaars, F. (2000): Building cross-cultural competence: How to create wealth from conflicting values. Chichester: John Wiley.

Hamplova, D./Nespor, Z.R. (2009): Invisible religion in a "non-believing" country: The case of the Czech Republic, in: Social Compass, 56, 4, 583.

Hansford, D. (2002): Insight into managing an age-diverse work force, in: Workspan, 45, 6, 48-53.

Helson, R./Jones, C./Kwan, V.S.Y. (2002): Personality change over 40 years of adulthood: Hierarchical linear modeling analyses of two longitudinal samples, in: Journal of Personality and Social Psychology, 83, 3, 752-766.

Hentley, R. (2006): The world according to Y: Inside the new generation. Crows Nest, NSW Australia: Allen \& Unwin.

Hofstede, G. (1980): Culture's consequences: International differences in work related values. London: Sage.

Hofstede, G. (1997): Cultures and organizations. New York: McGraw-Hill.

Hofstede, G. (2001): Culture's consequences: Comparing values, behaviors, institutions, and organizations across nations ( $2^{\text {nd }}$ ed.). Thousand Oaks: Sage.

House, R.J./Hanges, P.J./Javidan, M./Dorfman, P.W./Gupta, V. (eds.) (2004): Culture, leadership, and organizations: The GLOBE study of 62 societies. Thousand Oaks: Sage.

Inglehart, R.F./Welzel, C. (2005): Modernization, cultural change, and democracy: The human development sequence. New York: Cambridge University Press.

Kapetanovic, K. (2010): Managing and mobilizing millennials, in: Agrimarketing, St. Louis, 48, 8, 4749.

Keating, M.A./Martin, G.S./Szabo, E. (2002): Do managers and students share the same perceptions of societal culture?, in: International Journal of Intercultural Relations, 26, 6, 633-652.

Kluckhohn F./Strodtbeck, F.L. (1961): Variations in value orientations. New York: Harper Collins.

Kupperschmidt, B. (2000): Multigeneration employees: Strategies for effective management, in: Manager Magazine, 19, 64-69. 
Mead, R. (1998): International management: Cross-cultural dimensions. Malden: Blackwell Publishers Ltd.

Meuse, K./Mlodzik, K. (2010): A second look at generational differences in the workplace: Implication for HR and talent management, in: People and Strategy, 33, 50-59.

Nardon, L./Steers, R.M. (2009): The culture theory jungle: Divergence and convergence in models of national culture, in: Bhagat, R.S./Steers, R.M. (eds): Cambridge handbook of culture, organizations and work. Cambridge: Cambridge University Press, 3-22, DOI: 10.1017/CBO9780511581151.002

Newton, K. (2005): Managing the new generation of employees, in: Construction Distribution, Fort Atkinson, 8, 40-43.

Prašnikar, J./Pahor, M./Vidmar Svetlik, J. (2008): Are national cultures still important in international business? Russia, Serbia and Slovenia in comparison, in: Management, 13, 2, 1-26.

Rokeach, M. (1973): The nature of human values. New York: Free Press.

Schwartz, S.H. (1992): Universals in the content and structure of values: Theoretical advances and empirical tests in 20 countries, in: Zanna, M.P. (ed.): Advances in experimental social psychology, 25. New York: Academic Press, 1-65.

Schwartz, S.H./Bardi, A. (1997): Influences of adaptation to communist rule on value priorities in Eastern Europe, in: Political Psychology, 18, 2, 385-410.

Schwartz, S.H./Bardi, A./Bianchi, G. (2000): Value adaptation to the imposition and collapse of communist regimes in East-Central Europe, in: Renshon, S.A./Duckitt, J. (eds.): Political psychology: Cultural and cross-cultural foundations. London: Macmillan, 217-237.

Sujansky, J. (2010): Motivate your millennial employees, in: SuperVision, 71, 4, 14-15.

Tracz, E. (2009): Postawy młodzieży a pożądane cechy jej przyszłej pracy - na podstawie badań sondażowych studentów zarządzania, in: Juchnowicz, M. (ed.): Kulturowe uwarunkowania zarządzania kapitałem ludzkim. Krakow: Oficyna Wolter Kluwer, 146-159.

Trompenaars, F. (1993): Riding the waves of culture: Understanding cultural diversity in business. London: Brealey.

Trompenaars, F./Hampden-Turner, C. (1998): Riding the waves of culture: Understanding diversity in global business ( $2^{\text {nd }}$ ed.). New York: MacGraw-Hill.

Williams, R.M. (1979): Change and stability in values and value systems: A sociological perspective, in Rokeach, M. (ed.): Understanding human values: Individual and societal. New York: Free Press, 15-46.

http://europa.eu/about-eu/facts-figures/living/index_en.htm

http://www.europeanvaluesstudy.eu

http://www.state.gov/

*** Human Development Reports: http://hdr.undp.org/en/statistics/

*** Students in tertiary education, 2008 (1), available at: http://epp.eurostat.ec. europa.eu/statistics_explained/images/4/46/Students_in_tertiary_education\%2C_2008_\%281 \%29.png

*** World Bank: http://data.worldbank.org/data-catalog 